\title{
Contributions to the systematic of Pimelodidae (Osteichthyes, Siluriformes): basic and molecular cytogenetics on seven species of Pimelodus from three Brazilian hydrographic systems
}

\author{
Simone C. Girardi ${ }^{1,2}$, Carla S. Pavanelli ${ }^{2,3}$ and Vladimir P. Margarido ${ }^{1,2}$
}

Pimelodidae harbors several species and is widely distributed throughout the Neotropical region. Pimelodus is the genus with the largest number of species, however it is a polyphyletic group. Cytogenetic analyzes of the valid species still covers less than half of them. Herein, seven Pimelodus species from three Brazilian hydrographic systems were analyzed through basic (Giemsa, AgNORs and C banding) and molecular (5S and 18S rDNA-FISH) cytogenetic methods. All species had 2n=56 chromosomes with different karyotype formulas observed among the species. AgNORs were corresponding to 18S rDNA and localized on long arm of one chromosome pair in all species. Heterochromatin distribution follows the pattern commonly verified in the family and allows to identify each one of the studied species. $5 \mathrm{~S}$ rDNA marker was interspecifically variable in number and position of cistrons. Pimelodus ortmanni had B chromosomes varying intra and inter-individually. We performed a discussion on our own and available cytogenetic data for Pimelodidae, and the associating of them with available phylogeny enable us identifying features that distinguish subgroups within Pimelodidae, such as NORs location (terminal/long arm for species belonging to "Iheringichthys-Parapimelodus" and "Pimelodus maculatus" subclades) and location of 5S rDNA sites (pericentromeric/interstitial/ long arm for species belonging to Pimelodus group).

Keywords: 5S rDNA, 18S rDNA, B chromosome, Calophysus-Pimelodus clade, Citotaxonomy.

Pimelodidae abriga várias espécies e é amplamente distribuída ao longo da região Neotropical. Pimelodus é o gênero com o maior número de espécies, porém é um grupo polifilético. Análises citogenéticas foram realizadas em menos da metade das espécies válidas. Aqui, sete espécies de Pimelodus de três sistemas hidrográficos brasileiros foram estudadas através das técnicas citogenéticas básicas (Giemsa, AgRONs e banda C) e moleculares (FISH-DNAr 5S e 18S). Todas as espécies apresentaram $2 \mathrm{n}=56$ cromossomos, sendo observadas variações na fórmula cariotípica entre algumas espécies. As AgRONs correspondentes ao DNAr $18 \mathrm{~S}$ foram localizadas no braço longo de um par de cromossomos em todas as espécies. A heterocromatina segue o padrão comumente observado na família e permite identificar cada uma das espécies estudadas. O DNAr 5S apresentou variação interespecífica em número e na posição dos cístrons. Cromossomos B foram evidenciados em P. ortmanni com variação intra e interindividual. Nós discutimos os nossos resultados com os dados citogenéticos válidos para Pimelodidae, e a associação desses dados com a filogenia válida nos permitiu identificar características que distinguem subgrupos dentro de Pimelodidae, tais como a localização das RONs (terminal/braço longo para espécies pertencentes aos subclados "Iheringichthys-Parapimelodus" e "Pimelodus maculatus") e localização dos sítios de DNAr 5S (pericentromérico/ intersticial no braço longo para espécies pertencentes ao grupo Pimelodus).

Palavras-chave: Citotaxonomia, Clado Calophysus-Pimelodus, Cromossomo B, DNAr 5S, DNAr 18S.

\section{Introduction}

Pimelodidae is an endemic fish family from the Neotropical region belonging to the order Siluriformes, and comprises 114 valid species (Eschmeyer, Fong, 2018), presents a greater diversity of species in the basins of
Amazonas, Paraná and Orinoco, and greats rivers of the Guianas (Lundberg, Littman, 2003). Pimelodidae includes widely distributed species as well as locally endemic in the region of large rivers in northwestern Colombia and eastern Panamá, in Magdalena, Maracaibo, and in southwestern Brazil (Lundberg, Littman, 2003).

\footnotetext{
${ }^{1}$ Centro de Ciências Biológicas e da Saúde, Universidade Estadual do Oeste do Paraná, Rua Universitária, 2069, Jardim Universitário, 85819110 Cascavel, PR, Brazil. (SCG) sihgirardi@hotmail.com, (VPM) vladimir.margarido@unioeste.br, @ohttps://orcid.org/0000-0002-0823-6646 (corresponding author)

${ }^{2}$ Pós Graduação em Biologia Comparada, Universidade Estadual de Maringá, Av. Colombo, 5790, 87020-900 Maringá, PR, Brazil.

${ }^{3}$ Núcleo de Pesquisas em Limnologia, Ictiologia e Aquicultura (Nupélia), Universidade Estadual de Maringá, Av. Colombo, 5790, 87020-900 Maringá, PR, Brazil. carlasp@nupelia.uem.br
} 
Pimelodus Lacepède, 1803 is largely distributed throughout the Neotropical region, being the most diversified genus of Pimelodidae, with approximately 34 valid species (Eschmeyer et al., 2018). This genus does not present a monophyletic hypothesis, and the inclusion of species in this genus followed the non-cladistics characters, proposed even in the 19th century, which probably will lead many species to be relocated after phylogenetic studies (Ribeiro et al., 2008; 2011). This non-monophyletism is evident in the phylogenetic study of Lundberg et al. (2011), where the analyzed Pimelodus species were allocated in four clades with different genus. The Pimelodus group sensu by Lundberg et al. (2011) includes Pimelodus species and a sister clade formed by Iheringichthys and Parapimelodus, not being part of this group Pimelodus ornatus Kner, 1858 and Pimelodus cf. altissimus Eigenmann \& Pearson, 1942.

Cytogenetic studies in Pimelodidae are restricted to 34 valid species (Tab. 1). These studies show the prevalence of $2 n=56$ chromosomes with variations in the species of the Calophysines group, which have $2 \mathrm{n}=54$ and $2 \mathrm{n}=50$ chromosomes (Ramirez-Gil et al., 1998; Swarça et al., 1999; Vasconcelos, Martins-Santos, 2000; Swarça et al., 2001c; Sanchez et al., 2010; Carvalho et al., 2011), and in Pimelodus fur (Lütken 1874) with 2n=54 chromosomes (Garcia, Moreira-Filho, 2005, 2008). The pattern of simple telomeric nucleolar organizer regions (NORs) is common to all studied Pimelodidae, showing variation in position, short or long arm. Only fifteen species of this family have data on the location of $5 \mathrm{~S}$ and $18 \mathrm{~S}$ rDNA, which show variations in number and position (Tab. 1).

Although cytogenetic data are relatively scarce in Pimelodidae, they have contributed to the differentiation and identification of sympatric species, besides make possible the establishment of cytotaxonomic relationships among Pimelodidae species (Swarça et al., 2007). In this perspective, the increase of cytogenetic information can contribute to the classification and elucidation of uncertain relations in species of problematic genera, such as Pimelodus.

We present basic and molecular cytogenetic analyses of all the five species of Pimelodus with color pattern of black spots from the Brazilian part of the La Plata basin: Pimelodus britskii Garavello \& Shibatta, 2007 and Pimelodus ortmanni Haseman, 1911 are endemic of the Iguaçu River (Baumgartner et al., 2012); Pimelodus maculatus Lacèpede, 1803 is widely distributed, being found in the La Plata and São Francisco rivers basins; Pimelodus microstoma Steindachner, 1877 and Pimelodus paranaensis Britski \& Langeani, 1988 are present in the upper Paraná River (Eschmeyer et al., 2018). In addition, we carried out the same analyses in two species with the same coloration pattern that occur in adjacent basins: Pimelodus mysteriosus Azpelicueta, 1998 is located in the La Plata, the lower Uruguay, middle Paraná and Paraguay River, whereas Pimelodus absconditus Azpelicueta, 1995 on the La Plata River to the confluence with the Paraná and the Paraguay and Uruguay Rivers (Rocha, 2012).

This study reveals the first cytogenetic data of Pimelodus maculatus and P. absconditus of the Ijuí River population; first location of $5 \mathrm{~S}$ and $18 \mathrm{~S}$ rDNA in $P$. ortmanni and P. mysteriosus from the Iguaçu River downstream from the Cataratas do Iguaçu, and in $P$. paranaensis and P. microstoma from the Piquiri River, upper Paraná River basin. In addition, a review of cytogenetic studies in Pimelodidae is given with possible inferences about chromosome evolution in Pimelodus as well as in the family.

\section{Material and Methods}

Specimens of Pimelodus were collected and deposited in the Coleção Ictiológica do Núcleo de Pesquisas em Limnologia, Ictiologia e Aquicultura (NUPELIA) of the Universidade Estadual de Maringá, Brazil. The collecting sites and the voucher numbers are summarized in Tab. 2. This study was carried out in strict accordance with the recommendations of the Guide for the Care and Use of Laboratory Animals, approved by the Committee on the Ethics of Animal Experiments of the Universidade Estadual do Oeste do Paraná (License Number: Protocol 13/09 CEEAAP/Unioeste).

All specimens were anesthetized and euthanized by an overdose of clove oil according to Griffiths (2000). Chromosome preparations were obtained from cells of the anterior kidney by technique proposed by Bertollo et al. (1978). AgNORs were revealed by silver impregnation according to Howell, Black (1980) and C-banding following Sumner (1972), with modifications suggested by Lui et al. (2012). Physical mapping of the 5S rDNA and $18 \mathrm{~S}$ rDNA was carried out by fluorescence in situ hybridization (FISH) according to Pinkel et al. (1986) and modifications suggested by Margarido, Moreira-Filho (2008), using DNA probes obtained from Megaleporinus elongatus (Valenciennes, 1850) (Martins, Galetti-Junior, 1999) and from Prochilodus argenteus Spix \& Agassiz, 1829 (Hatanaka, Galetti-Junior, 2004), respectively. Probes were labeled by nick translation method with digoxigenin11-dUTP (5S rDNA) and biotin-16-dUTP (18S rDNA) (Roche $\left.{ }^{\circledR}\right)$. Detection of signals was performed with antidigoxigenin-rhodamine (Roche ${ }^{\circledR}$ ) for probe of $5 \mathrm{~S}$ rDNA and amplified avidin-FITC with biotinylated antiavidin (Sigma-Aldrich) for probe of $18 \mathrm{~S}$ rDNA, with the chromosomes counterstained with 4',6-diamidino2-phenylindole (DAPI, $50 \mu \mathrm{g} / \mathrm{mL}$ ). Metaphases were photographed using a BX 61 epifluorescence microscope, coupled with Olympus DP 71 digital camera (Olympus America, Inc.) with the Olympus DP Controller software 3.2.1.276. Chromosomes were classified and organized in accordance with Levan et al. (1964) in metacentric (m), submetacentric (sm), subtelocentric (st) and acrocentric (a). 


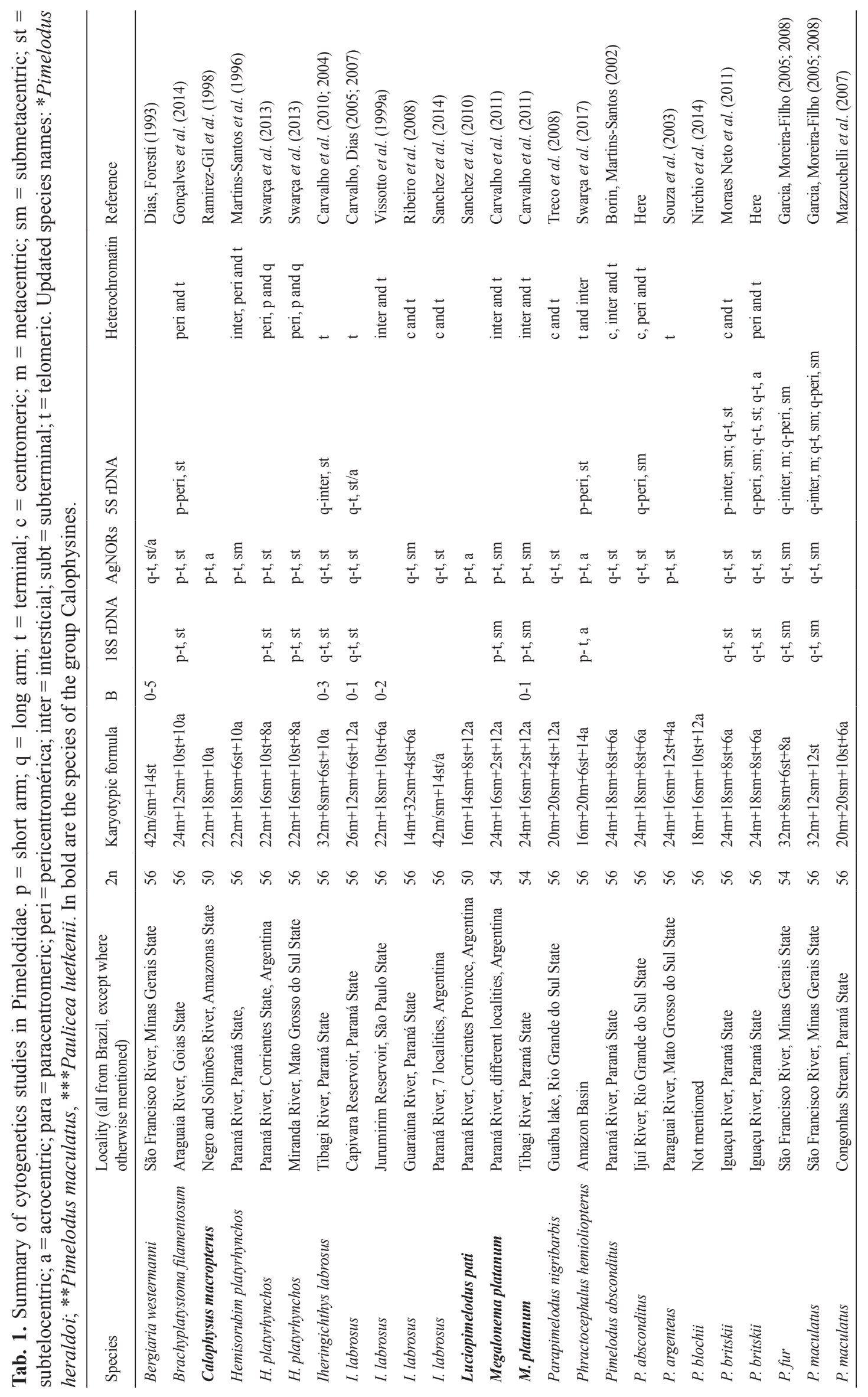




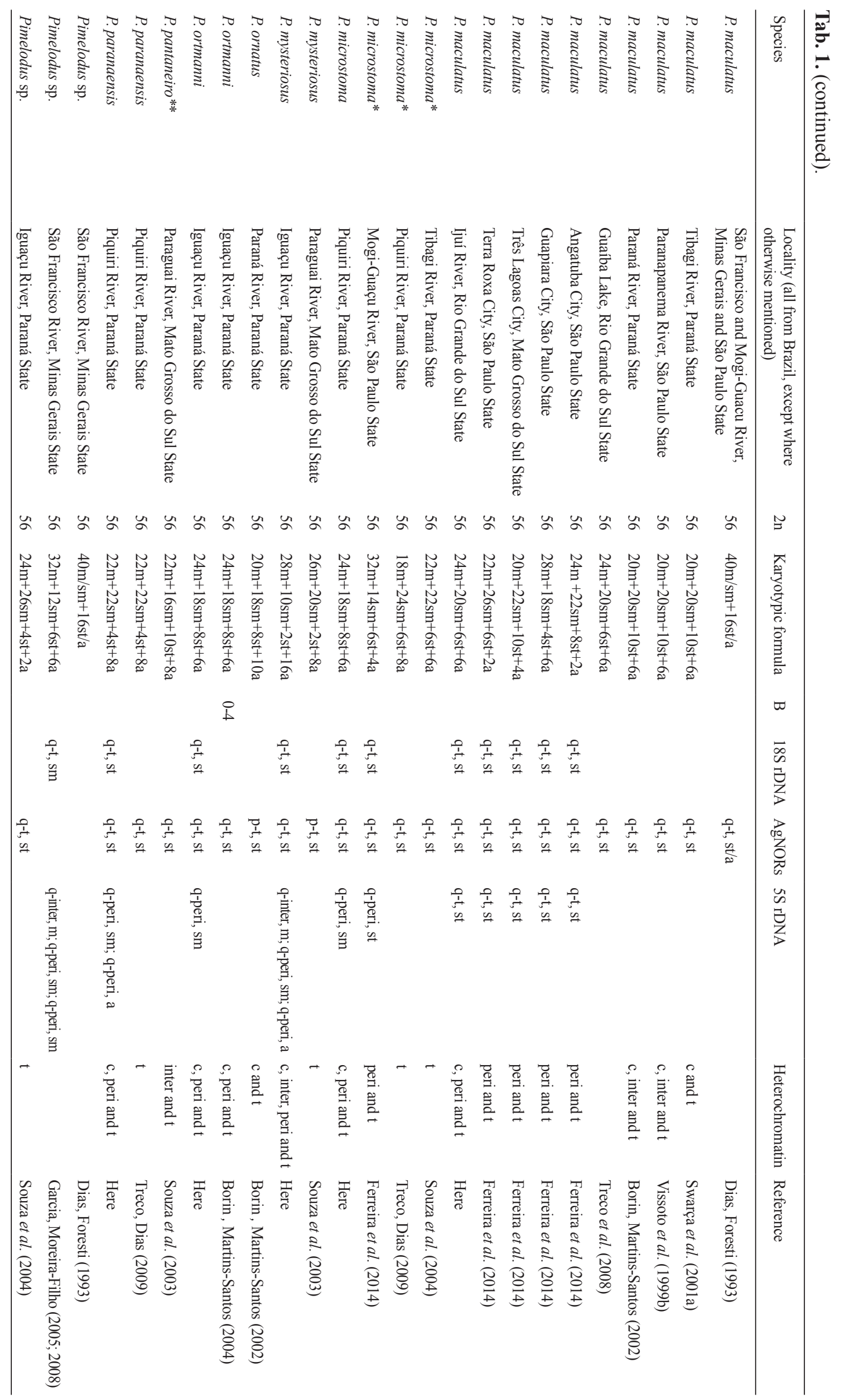




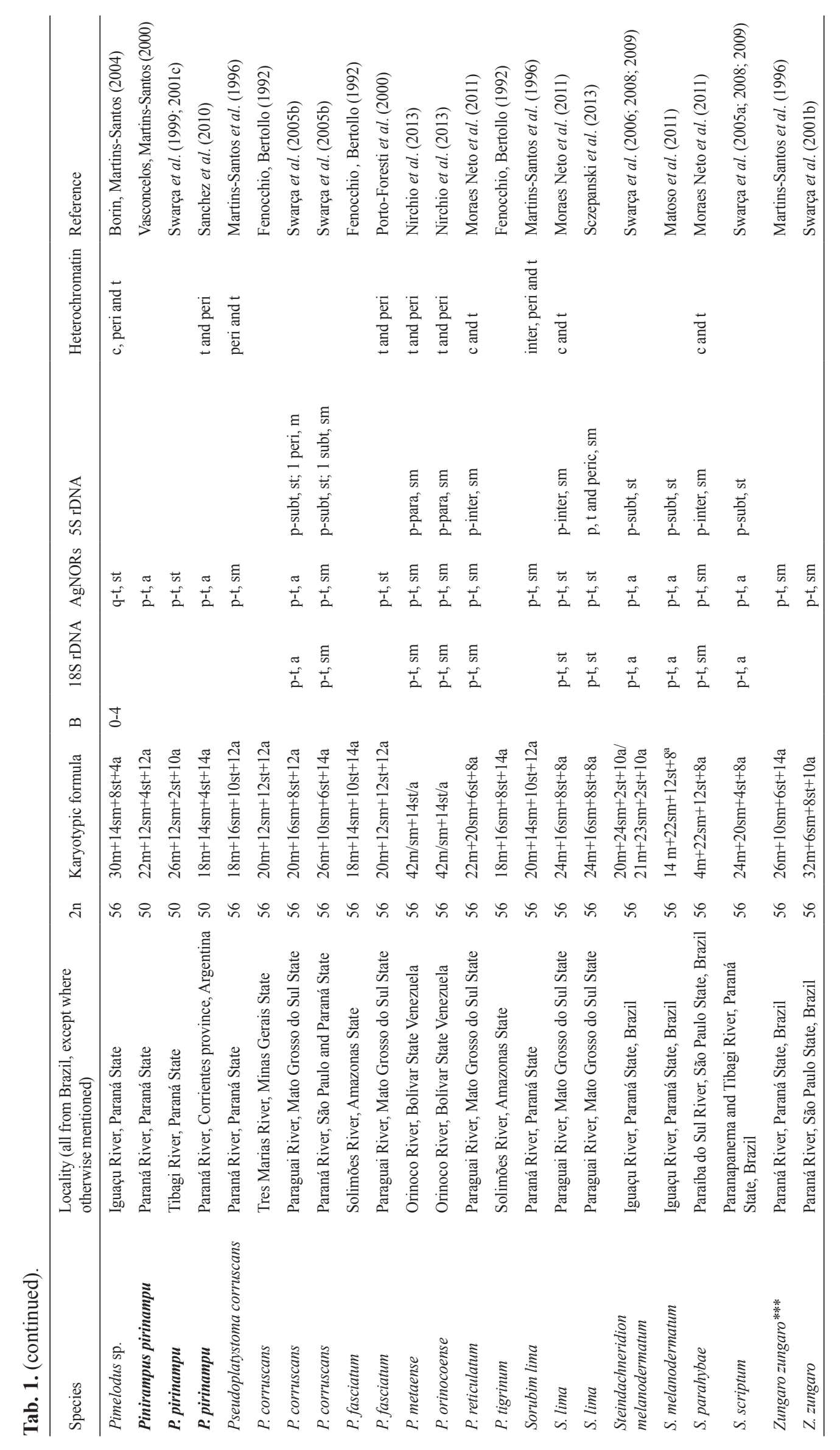


Tab. 2. Sample data of analyzed Pimelodus. *Population downstream from the Iguaçu Falls. $\hat{\delta}=$ male, $q=$ female, $U=$ Unidentified, NUP = voucher numbers of the Coleção Ictiológica do Nupélia.

\begin{tabular}{|c|c|c|c|c|c|c|c|}
\hline Species & Locality & Basin & Geographic Coordinates & $\hat{0}$ & 우 & $\mathrm{U}$ & NUP \\
\hline P. absconditus & Ijuí River & Upper Uruguai River & $28^{\circ} 18^{\prime} 06.3^{\prime \prime S} 53^{\circ} 53^{\prime} 33.6^{\prime \prime} \mathrm{W}$ & 17 & 6 & 1 & 17259,17264 \\
\hline P. britskii & Iguaçu River & Lower Iguaçu River & $25^{\circ} 37^{\prime} 13.20^{\prime \prime} \mathrm{S} 54^{\circ} 23^{\prime} 29.20^{\prime \prime} \mathrm{W}$ & 2 & 8 & 1 & $17260,17265,17266,17269$ \\
\hline P. maculatus & Ijuí River & Upper Uruguai River & $28^{\circ} 18^{\prime} 06.3^{\prime \prime} \mathrm{S} 53^{\circ} 53^{\prime} 33.6^{\prime \prime} \mathrm{W}$ & 1 & 3 & - & 17263 \\
\hline P. microstoma & Piquiri River & Upper Paraná River & $24^{\circ} 56^{\prime} 54^{\prime \prime S} 52^{\circ} 35^{\prime} 49^{\prime \prime} \mathrm{W}$ & 4 & 9 & - & 14938 \\
\hline P. mysteriosus* & Iguaçu River & Midlle Paraná River & $25^{\circ} 39^{\prime} 02^{\prime \prime} \mathrm{S} 54^{\circ} 27^{\prime} 25^{\prime \prime} \mathrm{W}$ & 1 & - & - & 16111 \\
\hline P. ortmanni & Iguaçu River & Lower Iguaçu River & $25^{\circ} 37^{\prime} 13.20^{\prime \prime S} 54^{\circ} 23^{\prime} 29.20^{\prime \prime} \mathrm{W}$ & 5 & 4 & 1 & $17261,17267,17270,17271$ \\
\hline P. paranaensis & Piquiri River & Upper Paraná River & $24^{\circ} 56^{\prime} 54^{\prime \prime} \mathrm{S} 52^{\circ} 35^{\prime} 49^{\prime \prime} \mathrm{W}$ & - & 2 & - & 14936,17274 \\
\hline
\end{tabular}

Tab. 3. Cytogenetics data obtained for Pimelodus species. $\mathrm{m}=$ metacentric; $\mathrm{sm}=$ submetacentric; $\mathrm{st}=$ subtelocentric; $\mathrm{a}=$ acrocentric; $\mathrm{p}=$ short arm; $\mathrm{q}=$ long arm; tel = telomeric; peri = pericentromeric; inter = interstitial.

\begin{tabular}{llccc}
\hline Species & Karyotypic Formula & Heterochromatin (C-banding) & AgNORs/18S rDNA & 5S rDNA \\
\hline P. absconditus & $24 \mathrm{~m}+18 \mathrm{sm}+8 \mathrm{st}+6 \mathrm{a}$ & Centromeric, pericentromeric and telomeric & tel q (24) & peri q (pair 18) \\
P. britskii & $24 \mathrm{~m}+18 \mathrm{sm}+8 \mathrm{st}+6 \mathrm{a}$ & Pericentromeric and telomeric & tel q (23) & peri q (pair 17); tel q (pairs 23 and 28) \\
P. maculatus & $24 \mathrm{~m}+20 \mathrm{sm}+6 \mathrm{st}+6 \mathrm{a}$ & Centromeric, pericentromeric and telomeric & tel q (23) & tel q (pair 23) \\
P. microstoma & $24 \mathrm{~m}+18 \mathrm{sm}+8 \mathrm{st}+6 \mathrm{a}$ & Centromeric, pericentromeric and telomeric & tel q (24) & peri q (pair 18) \\
P. mysteriosus & $28 \mathrm{~m}+10 \mathrm{sm}+2 \mathrm{st}+16 \mathrm{a}$ & Centromeric, interstitial, pericentromeric and telomeric & tel q (20) & inter q (pair 1); peri q (pair 21 and 22) \\
P. ortmanni & $24 \mathrm{~m}+18 \mathrm{sm}+8 \mathrm{st}+6 \mathrm{a}$ & Centromeric, pericentromeric and telomeric & tel q (24) & peri q (pair 18) \\
P. paranaensis & $22 \mathrm{~m}+22 \mathrm{sm}+4 \mathrm{st}+8 \mathrm{a}$ & Centromeric, pericentromeric and telomeric & tel q (24) & peri q (pairs 13, 18 and 26) \\
\hline
\end{tabular}

\section{Results}

The results are summarized in Tab. 3 and are presented below.

Pimelodus absconditus. We found a diploid number of 56 chromosomes $(24 \mathrm{~m}+18 \mathrm{sm}+8 \mathrm{st}+6$ a) (Fig. 1a). The AgNORs were located in the terminal region of the long arm of a pair of subtelocentric chromosomes (24) (Fig. 1a, box). C-banding revealed the existence of pale heterochromatin in the most of the centromeres of chromosomes, with some pairs showing heterochromatin conspicuous in the telomeric region of the short arm (pars 17 and 18) and the long arm (pair 24 ), in both telomeres (pairs 8 and 20), in the pericentromeric region of the long arm of pair 18 and in subterminal region of the long arm of pair 17 (Fig. 2a). The 18S rDNA was located on the subtelocentric chromosome pair (24), which corresponds to the AgNORs, while the 5S rDNA was found in the pericentromeric region of the long arm of pair 18 (Fig. 3a).

Pimelodus britskii. The diploid number of this species was also 56 chromosomes $(24 \mathrm{~m}+18 \mathrm{sm}+8 \mathrm{st}+6 \mathrm{a})$ (Fig. 1b). The AgNORs were located in the terminal region of the long arm of a pair of subtelocentric chromosomes 23 (Fig. 1b, box). $\mathrm{C}$-banding revealed the existence of pale heterochromatin in the region of the telomeres of some chromosomes, with more conspicuous heterochromatin being found in the telomeric region of the long arm (pairs 3, 6 and 23), in the subterminal region of the long arm (pair 15), pericentromeric region of the short arm (pair 2) and in long arm in pair 17 (Fig. 2b). The $18 \mathrm{~S}$ rDNA was located on the subtelocentric chromosome pair (23), which corresponds to the AgNORs, while the 5S rDNA was found at multiple sites, located in the pericentromeric region of the long arm of pair 17 and terminal region of the long arm of pairs 23 and 28 (Fig. 3b).

Pimelodus maculatus. The diploid number of this species was also 56 chromosomes $(24 \mathrm{~m}+20 \mathrm{sm}+6 \mathrm{st}+6 \mathrm{a})$ (Fig. 1c). The AgNORs were located in the terminal region of the long arm of a pair of subtelocentric chromosomes 23 (Fig. 1c, box). C-banding revealed the existence of pale heterochromatin in the region of the telomeres of some chromosomes, with more conspicuous heterochromatin being found in the telomeric region of the short arm (pair 6) and long arm (pairs 17, 22, 23 and 24), in both telomeres (pair 8) and the pericentromeric region of the short arm (pairs 1 and 25) and in long arm in pair 21 (Fig. 2c). The 18S rDNA and 5S rDNA showed syntenic sites in the terminal region of the long arm of a pair of subtelocentric chromosomes (23), which corresponds to the AgNORs (Fig. 3c).

Pimelodus microstoma. The diploid number was also 56 chromosomes $(24 \mathrm{~m}+18 \mathrm{sm}+8 \mathrm{st}+6$ a) (Fig. 1d). The AgNORs were located in the terminal region of the long arm of a pair of subtelocentric chromosomes 24 (Fig. 1d, box). C-banding highlighted pale heterochromatin in the region of the centromere in the most of chromosomes, with more conspicuous heterochromatin being found in the telomeric region of the short arm (4) and long arm (pairs 16 and 24), in both telomeres (pair 8) and in the pericentromeric region of the long arm in pair 18 (Fig. 2d). The 18S rDNA was located on the subtelocentric chromosome pair (24), which corresponds to the AgNORs, while the 5S rDNA was found in the pericentromeric region of the long arm of pair 18 (Fig. 3d). 

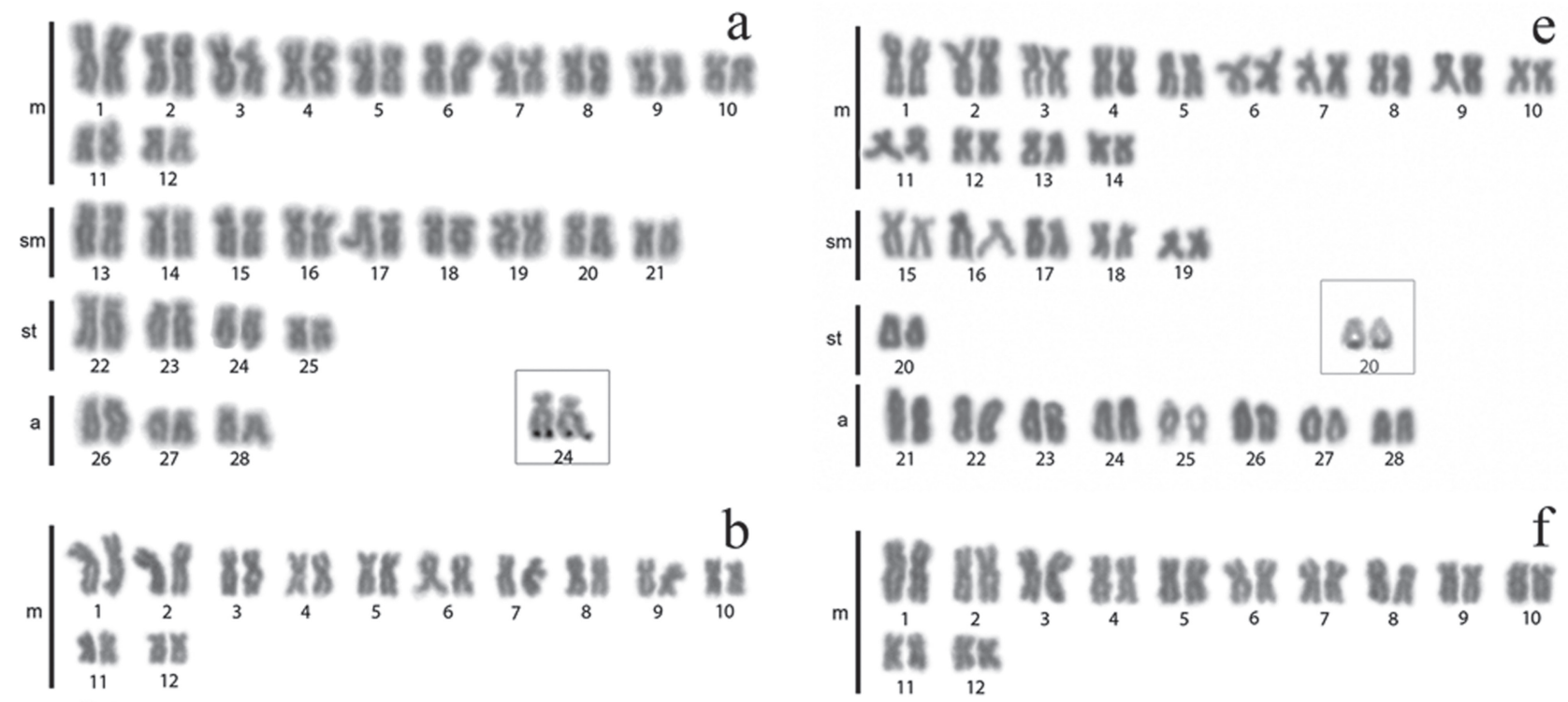

b

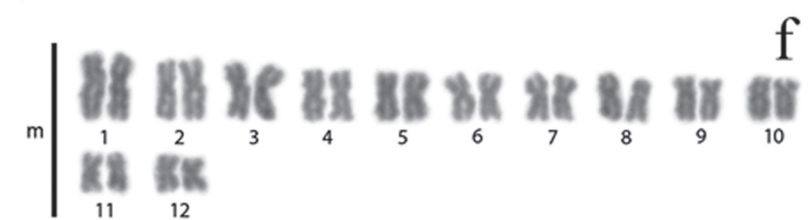

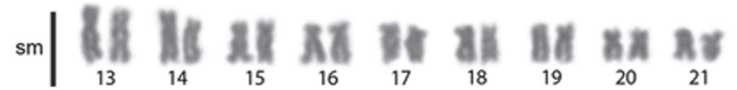

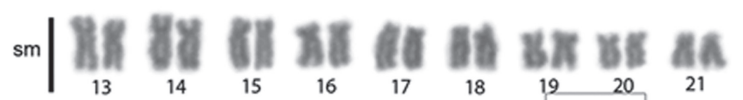

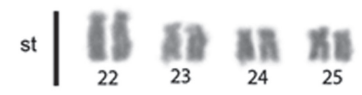

a| \begin{tabular}{|ccc}
28 & 11 & 16
\end{tabular}

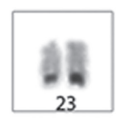

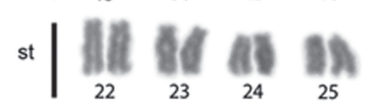

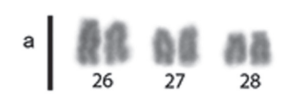

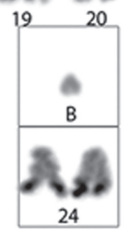

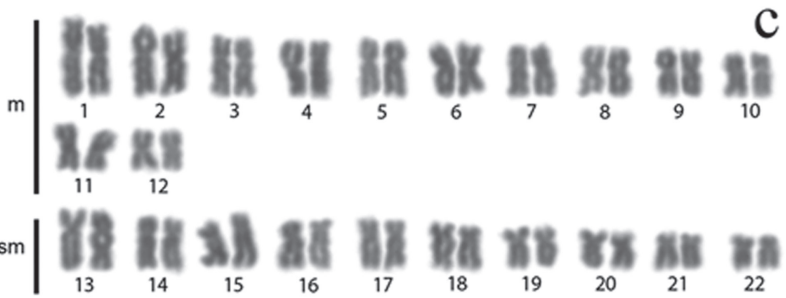

sm |

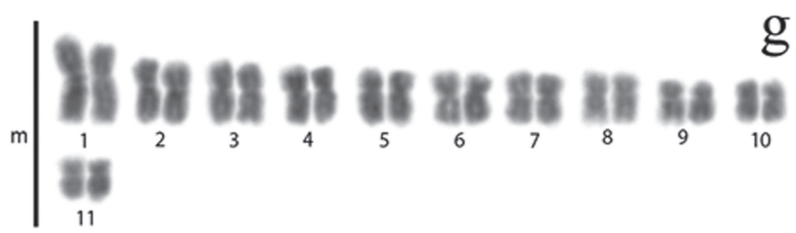

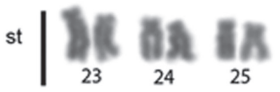

a |

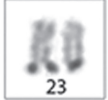

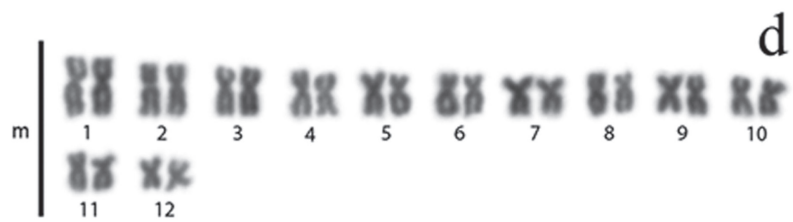

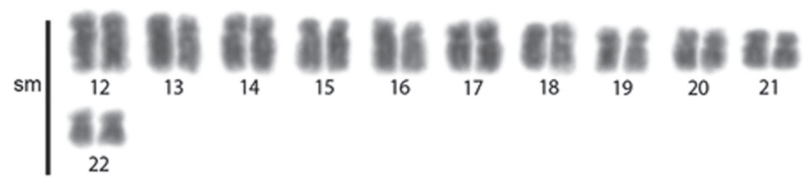

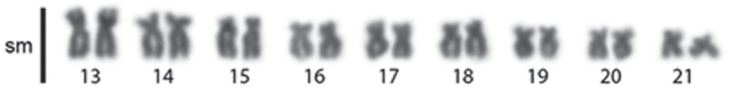

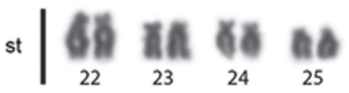

a $\underset{26}{\mathbf{1 1}} \underset{27}{06} \underset{28}{\mathbf{0 6}}$

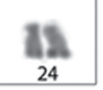

Fig. 1. Karyotypes arranged from Giemsa-stained chromosomes. a. Pimelodus absconditus; b. Pimelodus britskii; c. Pimelodus maculatus; d. Pimelodus microstoma; e. Pimelodus mysteriosus; f. Pimelodus ortmanni; g. Pimelodus paranaensis. Pairs of the AgNORs and B chromosomes are in the boxes. Scales bar $=10 \mu \mathrm{m}$. 

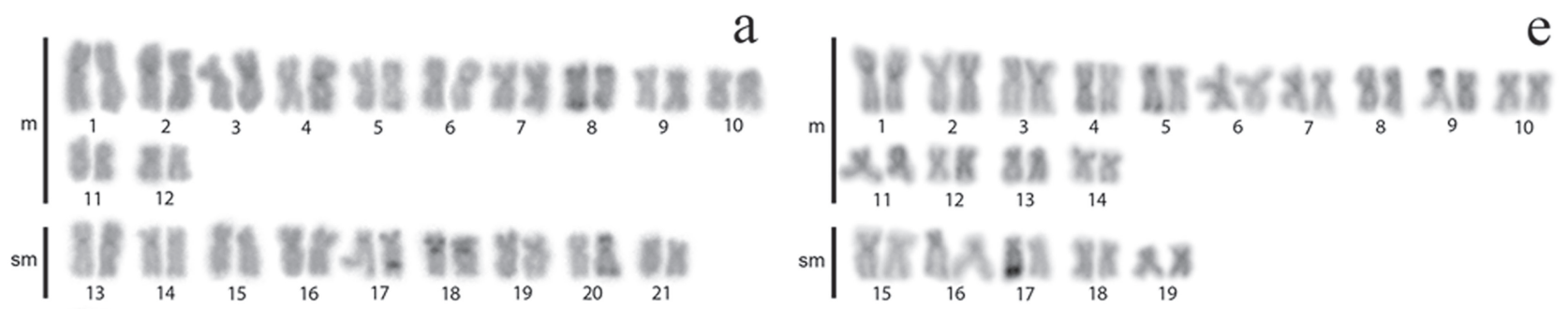

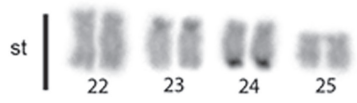
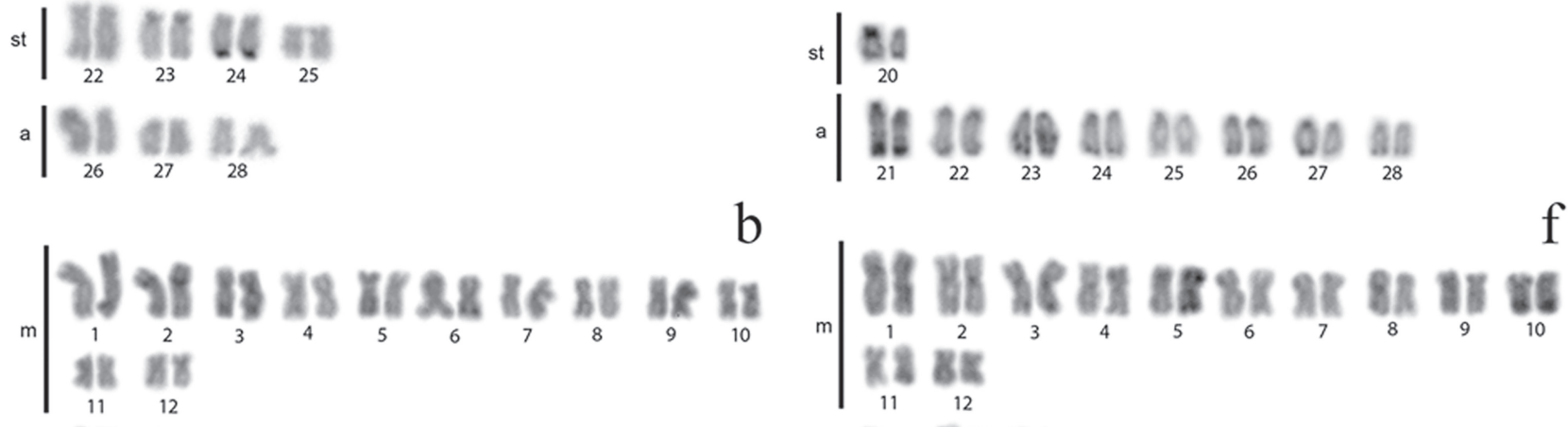

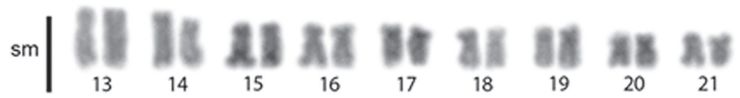

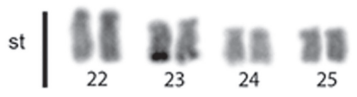

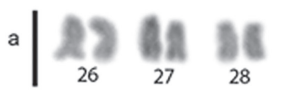
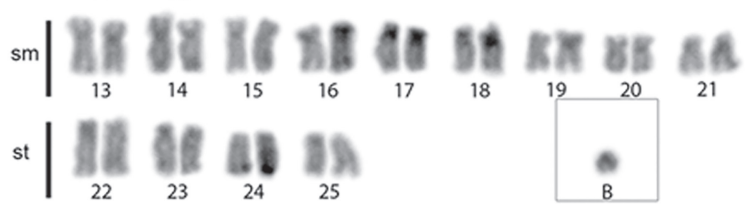

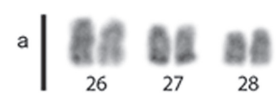

C
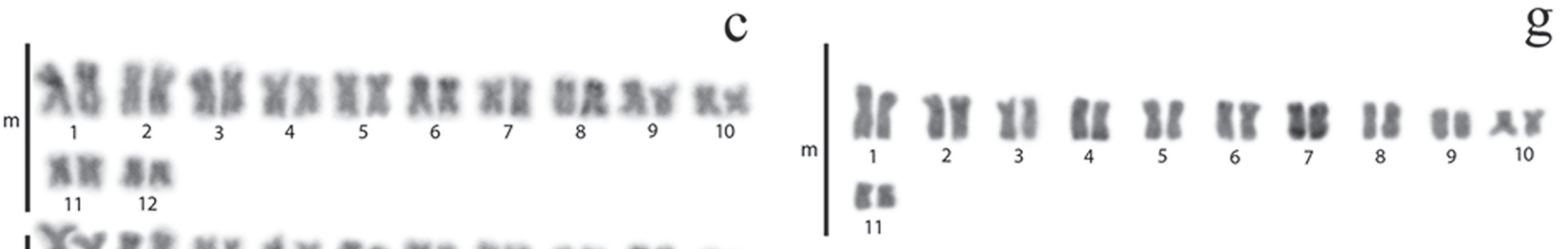

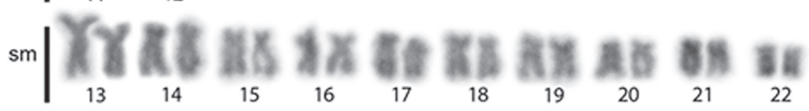

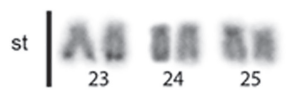

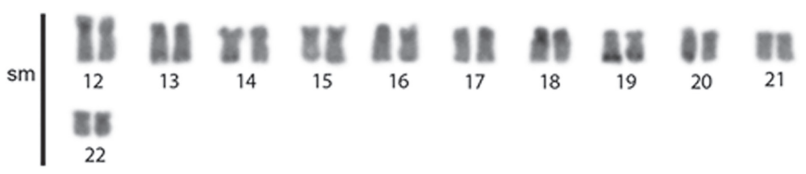

a|

st $\mid \underset{23}{|0|}$

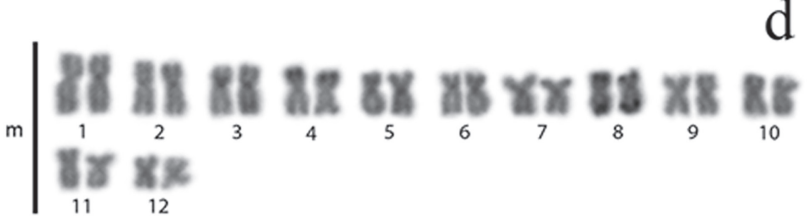

\begin{tabular}{ll|llll}
$\mathbf{d}$ & a & $\mathbf{1 0}$ & $\mathbf{1 0}$ & $\mathbf{1 0}$ & $\mathbf{1 0}$
\end{tabular}

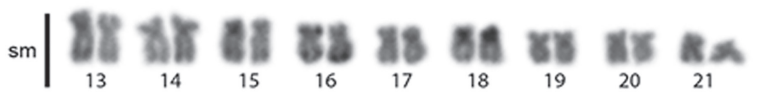

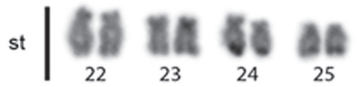

a $\underset{26}{\operatorname{and}} \underset{27}{\mathbf{A}} \underset{28}{\mathrm{nh}}$

Fig. 2. Karyotypes arranged from C-banded chromosomes. a. Pimelodus absconditus; b. Pimelodus britskii; $\mathbf{c}$. Pimelodus maculatus; d. Pimelodus microstoma; e. Pimelodus mysteriosus; f. Pimelodus ortmanni; g. Pimelodus paranaensis. B chromosomes in the boxes. Scales bar $=10 \mu \mathrm{m}$. 

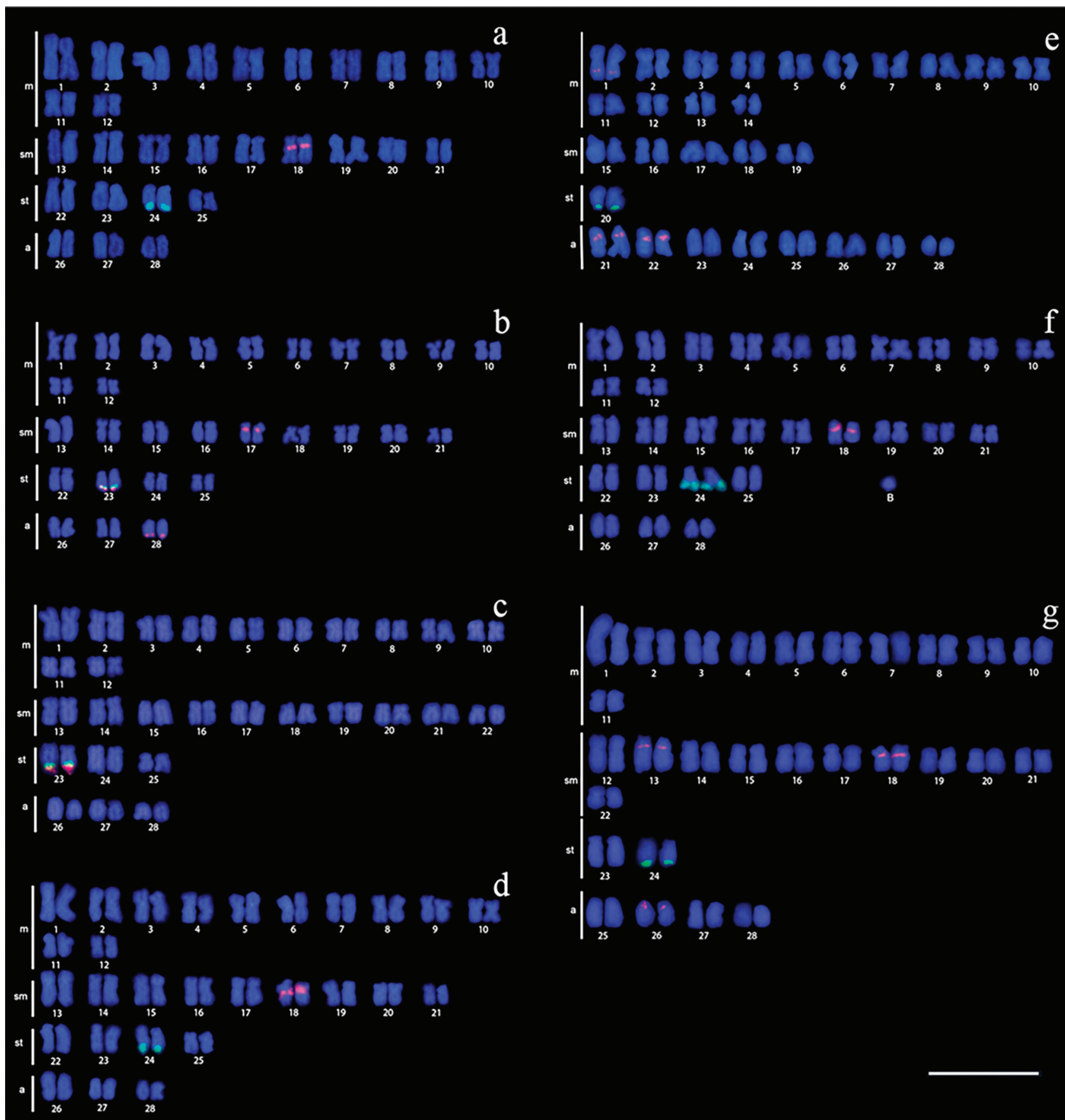

Fig. 3. Karyotypes after FISH with 5S rDNA probes (red) and 18S rDNA probe (green). a. Pimelodus absconditus; b. Pimelodus britskii; c. Pimelodus maculatus; d. Pimelodus microstoma; e. Pimelodus mysteriosus; f. Pimelodus ortmanni; g. Pimelodus paranaensis. Scales bar $=10 \mu \mathrm{m}$.

Pimelodus mysteriosus. The diploid number was also 56 chromosomes $(28 \mathrm{~m}+10 \mathrm{sm}+2 \mathrm{st}+16 \mathrm{a})$ (Fig. 1e). The AgNORs were located in the terminal region of the long arm of a pair of subtelocentric chromosomes 20 (Fig. 1e, box). $\mathrm{C}$-banding highlighted pale heterochromatin in the region of the centromere in the most of chromosomes, with more conspicuous heterochromatin being found in the telomeric region of the short arm (pair 20) and long arm (pairs 5, 17,
20, 21, 22, 23, 24, 26, 27 and 28), in interstitial region (pairs 21 and 23) and in the pericentromeric region of the long arm of pairs 21 and 22 (Fig. 2e). The 18S rDNA was located on the subtelocentric chromosome pair (20), which corresponds to the AgNORs, while the 5S rDNA was found at multiple sites, located in the interstitial region of the long arm of pair 1 and pericentromeric region of the long arm of pairs 21 and 22 (Fig. 3e). 
Pimelodus ortmanni. The diploid number was also 56 chromosomes $(24 \mathrm{~m}+18 \mathrm{sm}+8 \mathrm{st}+6$ a) (Fig. 1f). Among one to four $\mathrm{B}$ chromosomes (micro-chromosomes and acrocentric) (Fig. 1f) were observed in all specimens, with intra- and inter-individual variation (Tab. 4). The AgNORs were located in the terminal region of the long arm of a pair of subtelocentric chromosomes 24 (Fig. 1f, box). C-banding revealed the existence of pale heterochromatin in the region of the telomeres and centromeres of some chromosomes, with more conspicuous heterochromatin being found in the telomeric region of short arm (pair 16) and long arm (pairs 10, 24 and 27), in both telomere (pair 5) and in the pericentromeric region of the long arm (pairs 17 and 18), while the $\mathrm{B}$ chromosomes are entirely heterochromatic (Figs. 2f, 4). The 18S rDNA was located on the subtelocentric chromosome pair (24), which corresponds to the AgNORs, while the $5 \mathrm{~S}$ rDNA was found in the pericentromeric region of the long arm of pair 18 (Fig. 3f).

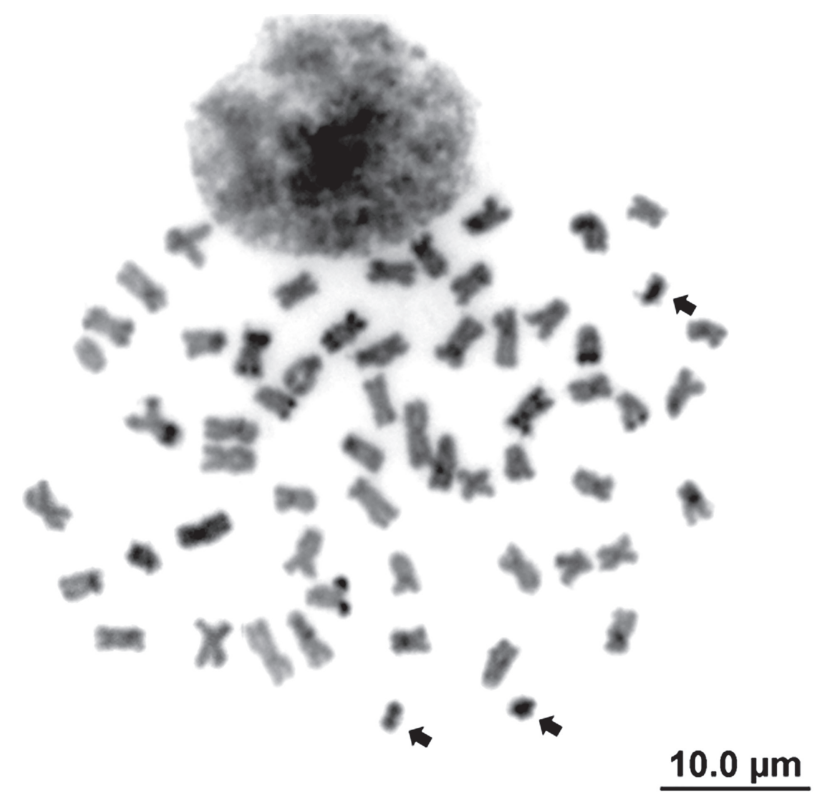

Fig. 4. C-banded metaphase of Pimelodus ortmanni. Arrows indicate the heterochromatic B chromosomes. Scales bar $=10 \mu \mathrm{m}$.
Pimelodus paranaensis. The diploid number of this species was also 56 chromosomes $(22 \mathrm{~m}+22 \mathrm{sm}+4$ st +8 a) (Fig. 1g). The AgNORs were located in the terminal region of the long arm of a pair of subtelocentric chromosomes 24 (Fig. 1g, box). C-banding highlighted pale heterochromatin in the region of the telomere in the most of chromosomes, with more conspicuous heterochromatin being found in the telomeric region of long arm (pairs 4, 13, 19, 20, 24 and 26), in both telomeres (pairs 7 and 23), in the pericentromeric region of the long arm (pairs 13, 18 and 26) and short arm (pairs 2 and 12) (Fig. 2g). The 18S rDNA was located on the subtelocentric chromosome pair (24), which corresponds to the AgNORs, while the 5S rDNA was found at multiple sites, located in the pericentromeric region of the long arm of pairs 13, 18 and 26 (Fig. 3g).

\section{Discussion}

The presence of $2 \mathrm{n}=56$ chromosomes in all species of Pimelodus studied here and in most species of Pimelodidae (Tab. 1) supports the hypothesis by MoraesNeto et al. (2011) that this is the ancestral diploid number for the family. Variations in this pattern were observed in Calophysines sensu Lundberg et al. (2011) (Fig. 5), such as Calophysus macropterus (Lichtenstein, 1819) $2 \mathrm{n}=50$ chromosomes (Ramirez-Gil et al., 1998), Luciopimelodus pati (Valenciennes, 1835) $2 \mathrm{n}=50$ chromosomes (Sanchez et al., 2010), Megalonema platanum (Günther, 1880) $2 \mathrm{n}=54$ chromosomes (Carvalho et al., 2011) and Pinirampus pirinampu (Spix \& Agassiz, 1829) $2 \mathrm{n}=50$ chromosomes (Swarça et al., 1999, 2001c; Vasconcelos, Martins-Santos, 2000; Sanchez et al., 2010). The only other exception was found in the also black spotted congener, Pimelodus fur $2 \mathrm{n}=54$ chromosomes (Garcia, Moreira-Filho, 2008), which inhabits the São Francisco River basin. The reduction of the diploid number in those species represents a derived feature in the family possibly originated from an independently chromosome fusion process, due to the phylogenetic distance between those groups.

Tab. 4. Frequency of B chromosomes in Pimelodus ortmanni from the Iguaçu River. *Unidentified.

\begin{tabular}{|c|c|c|c|c|c|c|c|c|}
\hline Specimems & Sex & $0 \mathrm{~B}$ & $1 \mathrm{~B}$ & $2 \mathrm{~B}$ & $3 \mathrm{~B}$ & $4 \mathrm{~B}$ & Total & Cells with B (\%) \\
\hline 3000 & q & - & 19 & - & - & - & 19 & 100 \\
\hline 3001 & $0^{\pi}$ & 4 & 3 & - & - & - & 7 & 42,9 \\
\hline 3084 & $0^{\lambda}$ & 3 & 5 & 1 & - & - & 9 & 66,7 \\
\hline 3143 & $\pi$ & - & 2 & - & 4 & 9 & 15 & 100 \\
\hline 3146 & 우 & - & 6 & - & 1 & - & 7 & 100 \\
\hline 3151 & 우 & - & 2 & 13 & - & - & 15 & 100 \\
\hline 3276 & 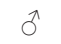 & - & 27 & 17 & 5 & 18 & 67 & 100 \\
\hline 3281 & $\hat{0}$ & 13 & 9 & 3 & - & - & 25 & 48 \\
\hline 3287 & $*$ & - & - & 21 & 37 & 2 & 60 & 100 \\
\hline 3288 & 우 & - & 2 & 4 & 15 & - & 21 & 100 \\
\hline Total (\%) & & $20(8,2)$ & $75(30,6)$ & $59(24,1)$ & $62(25,3)$ & $29(11,8)$ & 245 & \\
\hline
\end{tabular}


Single terminal NORs are common to all studied Pimelodidae species (Tab. 1), indicating that this feature was conserved during the process of karyotypic evolution of the family. Swarça et al. (2007) suggested the delimitation of two cytotaxonomic groups based on the location of NORs in the Pimelodidae species with $2 \mathrm{n}=56$ chromosomes: Surubiminae, NORs in the short arm, and Pimelodus, NORs in the long arm. All species of this study show these sequences in the terminal region of the long arm (Fig. 6) agreeing with the pattern shown in most Pimelodus species. We correlated cytogenetic data currently available (Tab.1) with the systematic classification proposed by Lundberg et al. (2011) (Fig. 5). The presence of NORs in the long arm is exclusive for species belonging to subgroups formed by the subclades "Iheringichthys-Parapimelodus" and "Pimelodus maculatus", while NORs in the short arm are present in the other groups and in some species currently attributed to Pimelodus. The location of these sequences in the short arm of most all the studied species and in basal node genera, Phractocephalus and Steindachneridion, allows inferring that this may be the primitive form for this character in this family, whereas the presence in the long arm would indicate the derived condition. It is likely that this feature originated from chromosomal inversions, and may be an important cytotaxonomic marker to distinguish species from these groups.

Regarding the distribution of heterochromatin, the Pimelodus species studied here follow the pattern found in Pimelodidae, that is, a small amount of heterochromatin, distributed in the telomere and centromere region, with some interstitial/pericentromeric markings (Fig. 6). This marker allows distinguishing studied Pimelodus species. Although $P$. absconditus and P. microstoma have similar patterns, $P$. absconditus presents two pairs ( 8 and 20) with heterochromatin in telomere of both arms and one pair (17) with subterminal heterochromatin, while $P$. microstoma shows only one pair with heterochromatin in telomere of both arms. Pimelodus britskii has heterochromatin in the pericentromeric region of the short arm of the second metacentric chromosome pair, which is also observed in $P$. paranaensis; however, in $P$. paranaensis there is a large number of pairs with telomeric bands, which does not occur in P. bristkii. Pimelodus mysteriosus contains a large number of heterochromatic blocks in the acrocentric chromosomes, which enable us to differentiate it from the other analyzed species. Heterochromatins in the pericentromeric region of the short arm on the first chromosome pair are exclusively observed in P. maculatus. Pimelodus ortmanni has a heterochromatin pattern similar to P. microstoma and P. absconditus, being differentiated by not having a pair of submetacentric chromosomes with heterochromatin in both telomeres. In P. microstoma, $P$. absconditus, P. ortmanni, P. paranaensis and P. maculatus the presence of a metacentric chromosome pair with conspicuous bi-telomeric heterochromatin was observed (Fig. 6); Garcia, Moreira-Filho (2005) reported that this characteristic has been observed in several species of Pimelodidae and Heptateridae, and hypothesized it as a marker for these families. However, the absence of this pattern in many species of both families makes difficult its effective use as marker.

The 5S rDNA sites show variations in number and position. Pimelodus microstoma, P. ortmanni, P. maculatus and $P$. absconditus presented single sites, whereas $P$. britskii, P. mysteriosus and P. paranaensis have three chromosomes pairs with these sequences (Fig. 6). According to Martins, Galetti-Junior (1999), the presence of 5S rDNA in only one pair of chromosomes probably represents the ancestral condition for fish. In Pimelodidae most species also presented a single chromosomes pair bearing $5 \mathrm{~S}$ rDNA sites (Tab. 1); however, in Pimelodus the prevalence is multiple sites, which may indicate the occurrence of chromosomal rearrangements like transposition / translocation during the speciation process of this group.

Despite the small number of species with data on the location of $5 \mathrm{~S}$ rDNA compared to the number of species in Pimelodidae, we can realize that species of the Pimelodus group sensu Lundberg et al. (2011) have these sites in the long arm, whereas species of the remaining Pimelodidae are evidenced in the short arm, and this can be an important cytotaxonomic marker. However, one exemplar of $P$. britskii has these sites in both, short and long arms (Moraes-Neto et al., 2011), indicating that analyzes of these sequences in a greater number of species are essential to confirm that hypothesis. Regarding the position of the $5 \mathrm{~S}$ rDNA sites, almost all the studied species in Pimelodidae have at least one pair with interstitial, pericentromeric or subterminal location, except for P. maculatus (Ferreira et al., 2014; and herein) and Iheringichthys labrosus (Lütken, 1874) (Carvalho, Dias, 2007) that have this sequence only in the telomeric region. According to Martins, GalettiJunior (2001), most fish species have the rDNA sites in the interstitial position, suggesting that such pattern is not casual and may represent some advantage related to the organization of these sequences in vertebrates.

The location of $5 \mathrm{~S}$ and $18 \mathrm{~S}$ rDNA genes in different chromosomes is the most common arrangement in fish (Martins, Galetti-Junior, 2001; Martins, Wasko, 2004). According to Martins, Galetti-Junior (1999), when the $45 \mathrm{~S}$ and $5 \mathrm{~S}$ genes are linked to the same chromosome disruptive interference may occur, such as translocations from $5 \mathrm{~S}$ to $45 \mathrm{~S}$, which could explain why the separate arrangement is the most common in vertebrates. However, cases of syntenic location of these sequences are reported in several Neotropical fish species (Bellafronte et al., 2005; Kavalco et al., 2004; Mariotto et al., 2011; Bueno et al., 2014; among others). In Pimelodidae, synteny of these sites are restricted to $P$. britskii (Moraes-Neto et al., 2011; and herein) and P. maculatus (herein), which may indicate a derived condition and possible phylogenetic proximity between these species, corroborating the taxonomic analyzes carried out by Rocha (2012). 

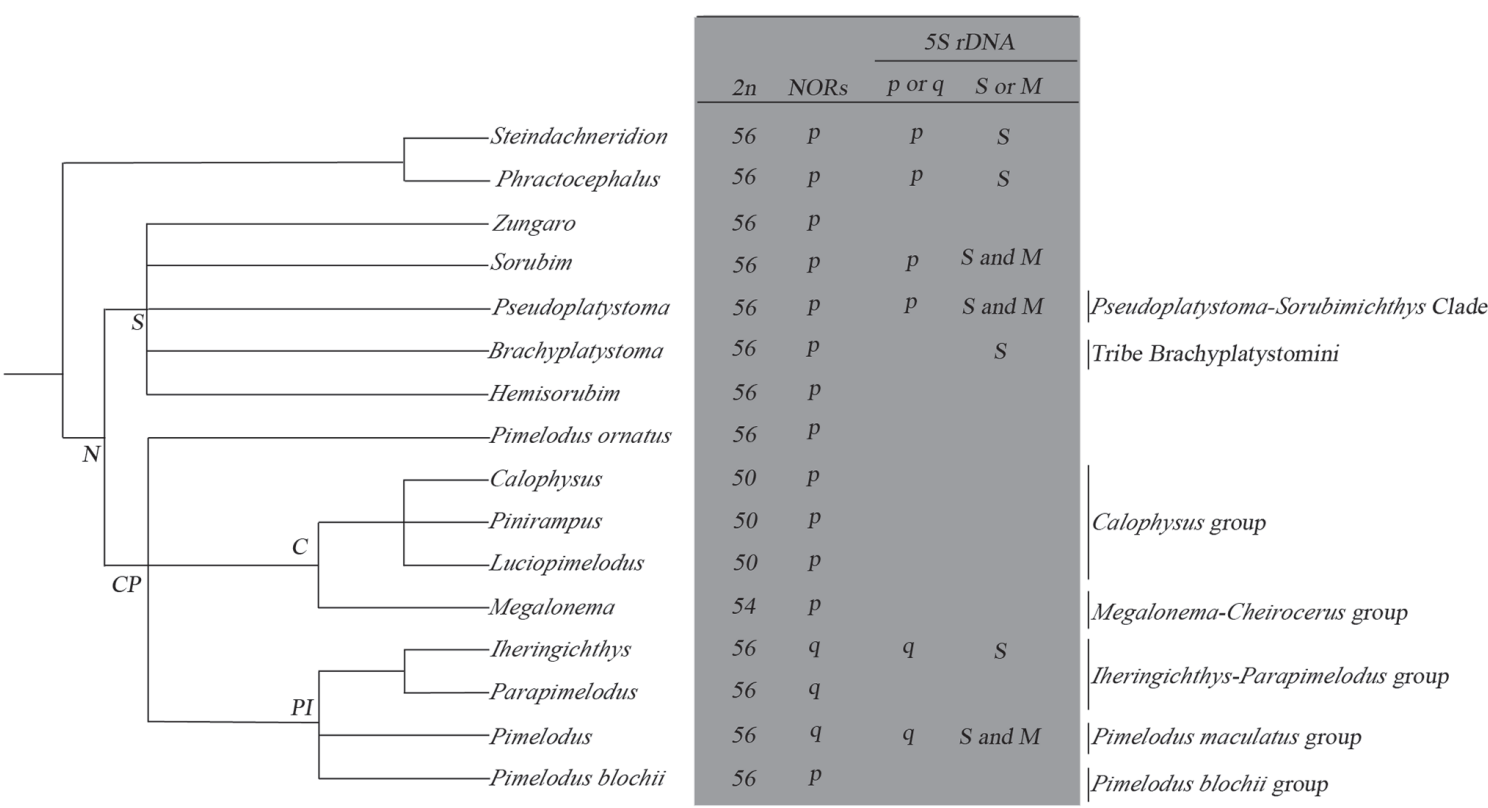

Fig. 5. Cytogenetics data and phylogenetic relationships between Pimelodidae (modified from Lundberg et al., 2011). $\mathrm{N}=$ Neopimelodines; $\mathrm{S}=$ Sorubimines; $\mathrm{CP}=$ Calophysus-Pimelodus Clade; $\mathrm{C}=$ Calophysines; $\mathrm{PI}=$ Pimelodus Group; $2 \mathrm{n}=$ number diploid; $\mathrm{p}=$ short arm; $\mathrm{q}=$ long arm; $\mathrm{S}=$ simple; $\mathrm{M}=$ multiple.
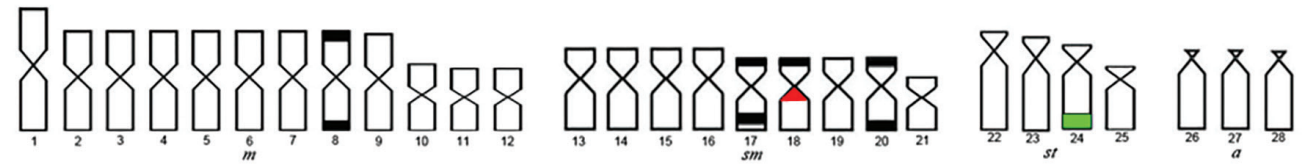

P. absconditus
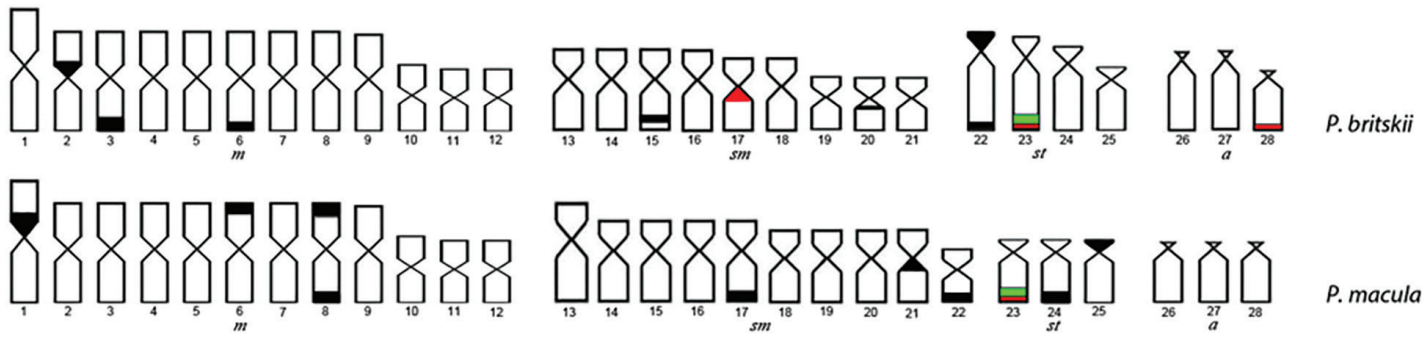

P. maculatus
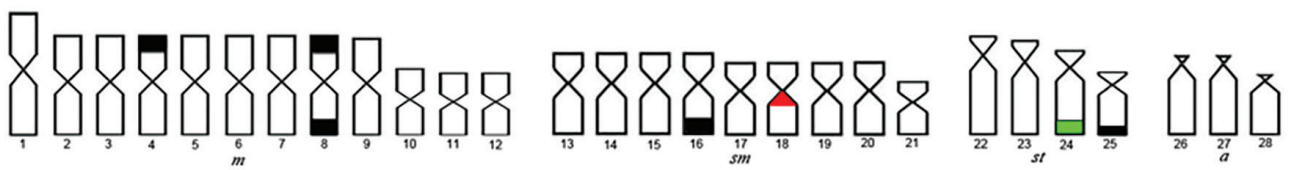

P. microstoma
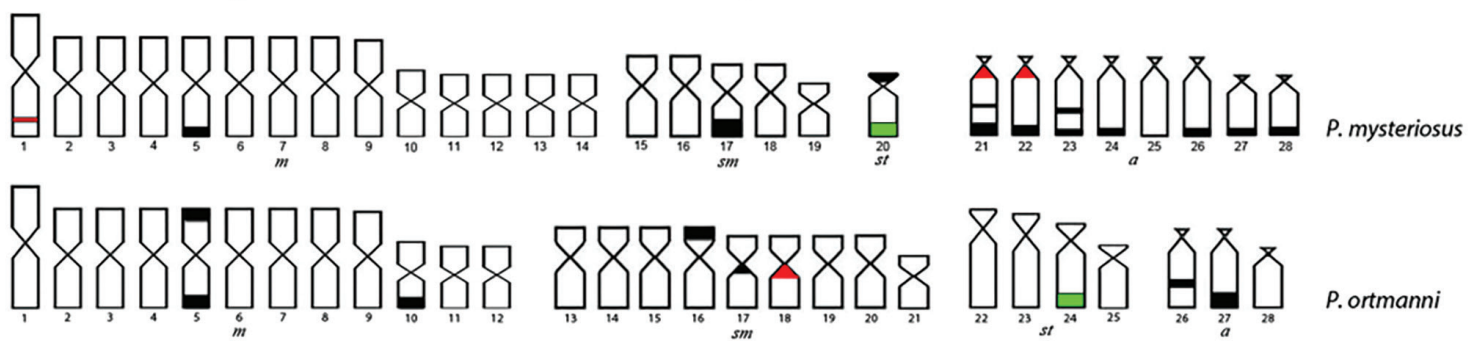

P. ortmanni
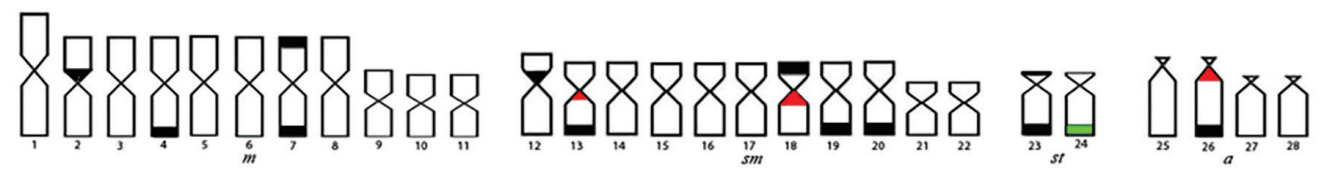

P. paranaensis

Fig. 6. Idiogram for the seven studied Pimelodus species with data obtained with different methodologies. Heterochromatin (black), 5S rDNA (red) and 18S rDNA (green). 
Chromosomes B are present in some individuals of some populations and, in some species, they are additional dispensable chromosomes that probably originated from complementary A chromosomes, but follow an evolutionary path of their own (Beukeboom, 1994). They are found in the main groups of animals and plants (Camacho et al., 2000). Pimelodus ortmanni presents B chromosomes in form of micro chromosomes and some acrocentric (Fig. 4), varying in number from 0 to 4 chromosomes per cell, occurring in more than $91 \%$ of the analyzed cells (Tab. 4). According to Camacho et al. (2000), the frequency of these chromosomes in natural populations depends on how much the species can tolerate these additional elements, and the strength of the accumulation mechanism and the maximum number of $\mathrm{B}$ chromosomes that the species is able to tolerate depends on the intensity of selective (environmental) factors, historical (number of generations since B origin), transmission factors and random factors (genetic drift). The $\mathrm{B}$ chromosomes in $P$. ortmanni were completely heterochromatic, being this characteristic observed in most cases (Camacho et al., 2000). In Pimelodidae they have been reported in Bergiaria westermanni (Lütken, 1874) (Dias, Foresti, 1993), I. labrosus (Vissotto et al., 1999a; Carvalho et al., 2004; Carvalho, Dias 2005; 2007; Carvalho et al., 2010), Megalonema platanum (Carvalho et al., 2011), Pimelodus ortmanni and Pimelodus sp. (Borin, Martins-Santos, 2004).

Pimelodus maculatus is widely distributed along the rivers La Plata, São Francisco, Paraná and Uruguay (Rocha, 2012). Cytogenetic studies in several populations show maintenance of the diploid number with variation in the karyotypic formula. According to Ferreira et al. (2014), these variations are subtle and may be related to different patterns of condensation of the chromosomal preparations or due to the fixation of distinct chromosomal rearrangements during the evolutionary process of each population. The population of the Ijuí River studied here presents a karyotypic formula and distribution pattern of heterochromatin similar to the Lake Guaíba population studied by Treco et al. (2008), which may indicate close evolutionary history between them. In the Ijuí River, $5 \mathrm{~S}$ rDNA was located in the terminal position of the long arm of a pair of subtelocentric chromosomes, and for the first time, it was observed syntenic with $18 \mathrm{~S}$ rDNA in P. maculatus. Populations of the Upper Paraná River studied by Ferreira et al. (2014) also show a single pair with 5S rDNA sites. Garcia, Moreira-Filho (2008) performed cytogenetic studies in the $P$. maculatus population of the São Francisco River and observed 5S rDNA in three pairs of chromosomes. These differences in the amount and arrangement of the $5 \mathrm{~S}$ rDNA sites may indicate the existence of more than one species. According to Ferreira et al. (2014), although the populations of the Upper Paraná and São Francisco river basins are not morphologically differentiated, PCR-RFLP data and genetic sequencing indicate the existence of genetically distinct but related groups, which corroborates the hypothesis also suggested by the authors.
We found the population of $P$. mysteriosus has $2 \mathrm{n}=56$ chromosomes $(28 \mathrm{~m}+10 \mathrm{sm}+2 \mathrm{st}+16 \mathrm{a})$, single NORs in the long arm of a subtelocentric pair, pale heterochromatic blocks in the region of the centromere with conspicuous blocks in the region of telomeres and centromeres of some chromosomes. These results, except for the diploid number, differ from that reported by Souza et al. (2003) for the $P$. mysteriosus population from the Paraguay River, which presents $26 \mathrm{~m}+20 \mathrm{sm}+2 \mathrm{st}+8 \mathrm{a}$, single NORs on the short arm of a subtelocentric pair and pale heterochromatin in the telomere region. These differences suggest the existence of more than one species, evidencing the need for further studies among populations from the Paraguay and Middle Paraná rivers.

The population of $P$. microstoma (cited as $P$. heraldoi) by Treco, Dias (2009) comes from the same basin as the exemplars of that species analyzed here. Despite the difference in the karyotypic formula, this should not indicate a real alteration but rather be a result of variations in chromosome condensation, which makes it difficult to classify the chromosomes and enables such differences in the organization of karyotypes among authors (MoraesNeto et al., 2011). In Neotropical fishes, cases of diploid number maintenance with variations in the karyotypic formula are recurrent, as for example in Iheringichthys labrosus (Carvalho, Dias 2005; Ribeiro et al., 2008), Parauchenipterus galeatus (Linnaeus, 1766) (Lui et al., 2010), Pseudoplatystoma corruscans (Spix \& Agassiz, 1829) (Swarça et al., 2005b) and Rhamdia quelen (Quoy \& Gaimard, 1824) (Martinez et al., 2011).

The cytogenetic data of Steindachneridion and Phractocephalus species show the diploid number of 56 chromosomes, simple NORs (Ag- and 18S rDNA) and single 5S rDNA in telomeric region on the short arm (Swarça et al., 2005a; Matoso et al., 2011; Moraes-Neto et al., 2011; Swarça et al., 2017). Cytogenetic studies in Pimelodidae indicate the features described above for Steindachneridion and Phractocephalus are observed in most analyzed species, and possibly represent the ancestral condition for the family. Different diploid number found in the species of the Calophysus-Pimelodus clade reflect a process of karyotype evolution divergent from the other Pimelodidae, and are considered derived condition in the family.

Our results increase cytogenetic information for Pimelodidae providing the first report of synteny between 18S and 5S DNAr genes in Pimelodus maculatus, and cytogenetic differences found reinforce the hypothesis of the existence of more than one species in which is currently attributed to the widespread $P$. maculatus. Associating cytogenetic data with available phylogeny enable us identifying features that distinguish subgroups within Pimelodidae, such as NORs location and position of the $5 \mathrm{~S}$ rDNA sites. Such data facilitate establishing relationships between groups and help understanding the chromosomal evolution of this family. 


\section{Acknowledgments}

The authors are thankful to the Instituto Chico Mendes de Conservação da Biodiversidade (MMA/ICMBio) for authorizing fish captures (License number: SISBIO 105221). Thanks are given to the Universidade Estadual do Oeste do Paraná (UNIOESTE), Parque Nacional do Iguaçu, Macuco Safari and Núcleo de Pesquisas em Limnologia, Ictiologia e Aquicultura (Núpelia) for logistical support. This study was financed by CAPES (Coordenadoria de Aperfeiçoamento de Ensino Superior), Fundação Araucária (Fundação Araucária de Apoio e Desenvolvimento Científico e Tecnológico do Estado do Paraná), CNPq (Conselho Nacional de Desenvolvimento Científico e Tecnológico) and FPTI (Fundação Parque Tecnológico Itaipu). This study was carried out in strict accordance with the recommendations of the Guide for the Care and Use of Laboratory Animals, approved by the Committee on the Ethics of Animal Experiments of the Universidade Estadual do Oeste do Paraná (License Number: Protocol 13/09 CEEAAP/Unioeste).

\section{References}

Baumgartner G, Pavanelli CS, Baumgartner D, Bifi AG, Debona T, Frana VA. Peixes do Baixo rio Iguaçu. Maringá: Eduem; 2012.

Bellafronte E, Margarido VP, Moreira-Filho O. Cytotaxonomy of Parodon nasus and Parodon tortuosus (Pisces, Characiformes). A case of synonymy confirmed by cytogenetic analyses. Genet Mol Biol [serial on the Internet]. 2005; 28(4):710-16. Available from: http://dx.doi.org/10.1590/S1415-47572005000500010

Bertollo LAC, Takahashi CS, Moreira-Filho O. Cytotaxonomic considerations on Hoplias lacerdae (Pisces, Erythrinidae). Braz J Genet. 1978; 1(2):103-20.

Beukeboom LW. Bewildering Bs: an impression of the 1st B-Chromosome Conference. Heredity. 1994; 73:328-36.

Borin LA, Martins-Santos IC. Cytogenetic aspects in species of the genus Pimelodus (Pisces, Siluriformes, Pimelodidae) of the river Paraná Basin. Cytologia. 2002; 67:199-204.

Borin LA, Martins-Santos IC. Study on karyotype and occurrence of $\mathrm{B}$ chromosomes in two endemic species of the genus Pimelodus (Siluriformes, Pimelodidae) from the river Iguaçu. Hereditas [serial on the Internet]. 2004; 140(3):201-09. Available from: https://doi.org/10.1111/j.1601-5223.2004.01812.x

Bueno V, Venere PC, Konerat JT, Zawadzki CH, Vicari MR, Margarido VP. Physical mapping of the 5S and 18S rDNA in ten species of Hypostomus Lacépède 1803 (Siluriformes: Loricariidae): evolutionary tendencies in the genus. Sci World $\mathrm{J}$ [serial on the Internet]. 2014; 2014:1-8. Available from: http://dx.doi.org/10.1155/2014/943825

Camacho JPM, Sharbel TF, Beukeboom LW. B-chromosome evolution. Philos Trans R Soc Lond B Biol Sci [serial on the Internet]. 2000; 355(1394):163-78. Available from: http://doi. org/10.1098/rstb.2000.0556

Carvalho RA, Giuliano-Caetano L, Dias AL. Cytogenetic analysis of A- and B- chromosomes of Iheringichthys labrosus (Pisces, Pimelodidae) from the Tibagi River, Paraná, Brazil. Cytologia [serial on the Internet]. 2004; 69(4):381-85. Available from: https://doi.org/10.1508/cytologia.69.381
Carvalho RA, Dias AL. Karyotypic characterization of Iheringichthys labrosus (Pisces, Pimelodidae): C-, G- and restriction endonuclease banding. Genet Mol Res. 2005; 4(4):663-67.

Carvalho RA, Dias AL. Interindividual size heteromorphism of NOR and chromosomal location of 5S rRNA genes in Iheringichthys labrosus. Braz Arch Biol Technol [serial on the Internet]. 2007; 50(1):141-46. Available from: http://dx.doi. org/10.1590/S1516-89132007000100017

Carvalho RA, Laudicina A, Giuliano-Caetano L, Martins-Santos IC, Dias AL. Cytogenetic analysis of the 18S, 5S rDNA and B chromosome of Iheringichthys labrosus (Lütken, 1874) (Siluriformes, Pimelodidae). Brazil J Biol [serial on the Internet]. 2010; 70(3):631-36. Available from: http://dx.doi. org/10.1590/S1519-69842010000300021

Carvalho RA, Sanchez S, Swarça AC, Fenocchio AS, MartinsSantos IC, Dias AL. Chromosomal analyses in Megalonema platanum (Siluriformes: Pimelodidae), an endangered species from South American rivers. Neotrop Ichthyol [serial on the Internet]. 2011; 9(1):177-82. Available from: http://dx.doi. org/10.1590/S1679-62252011005000008

Dias AL, Foresti F. Cytogenetic studies on fishes of the family Pimelodidae (Siluroidei). Rev Bras Genet [serial on the Internet].1993; 16(3):585-600. Available from: http://www. gmb.org.br/Revistas/V16/v16a051.pdf

Eschmeyer WN, Fong JD. Species by family/subfamily in Catalog of Fishes. [Electronic version]. San Francisco (CA): California Academy of Science; 2018. [cited March, 29, 2018]. Available from: http://researcharchive.calacademy.org/research/ ichthyology/catalog/SpeciesByFamily.asp

Eschmeyer WN, Fricke R, van der Laan R, editors. Catalog of fishes: genera, species, references [Internet]. San Francisco: California Academy of Science; 2018 [updated March, 29, 2018; cited March, 29, 2018]. Available from: http://researcharchive. calacademy.org/research/ichthyology/catalog/fishcatmain.asp

Fenocchio AS, Bertollo LAC. Karyotype similarities among Pimelodidae (Pisces, Siluriformes) from the Brazilian Amazon region. Cytobios. 1992; 69(276):41-46.

Ferreira M, Bressane KCO, Moresco ARC, Moreira-Filho O, Almeida-Toledo LF, Garcia C. Comparative application of direct sequencing, PCR-RFLP, and cytogenetic markers in the genetic characterization of Pimelodus (Siluriformes: Pimelodidae) species: Possible implications for fish conservation. Genet Mol Res [serial on the Internet]. 2014; 13(2):4529-44. Available from: http://dx.doi.org/10.4238/2014.June.17.5

Garcia C, Moreira-Filho O. Cytogenetical analyses in three fish species of the genus Pimelodus (Siluriformes: Pimelodidae) from rio São Francisco: considerations about the karyotypical evolution in the genus. Neotrop Ichthyol [serial on the Internet]. 2005; 3(2):285-90. Available from: http://dx.doi.org/10.1590/ S1679-62252005000200006

Garcia C, Moreira-Filho O. Localization of ribosomal genes in three Pimelodus species (Siluriformes, Pimelodidae) of the São Francisco River: $5 \mathrm{~S}$ genes as species markers and conservation of the 18S rDNA sites. Genet Mol Biol [serial on the Internet]. 2008; 31(1): 261-64. Available from: http://dx.doi.org/10.1590/ S1415-47572008000200018

Gonçalves ALM, Prado FD, Ferreira DC, Voltolin TA, Senhorini JA, Foresti F, Porto-Foresti F. First cytogenetic characterization of the giant Amazonian catfish Brachyplatystoma filamentosum (Siluriformes, Pimelodidae). Caryologia. 2014; 67(2):101-05. 
Griffiths SP. The use of clove oil as an anaesthetic and method for sampling intertidal rockpool fishes. J Fish Biol [serial on the Internet]. 2000; 57(6):1453-64. Available from: http://doi. org/10.1006/jfbi.2000.140

Hatanaka T, Galetti-Junior PM. Mapping of the $18 \mathrm{~S}$ and $5 \mathrm{~S}$ ribosomal RNA genes in the fish Prochilodus argenteus Agassiz, 1829 (Characiformes, Prochilodontidae). Genetica. 2004; 122(3):239-44.

Howell WM, Black DA. Controlled silver-staining of nucleolus organizer regions with a protective colloidal developer: a 1-step method. Experientia. 1980; 36(8):1014-15.

Kavalco KF, Pazza R, Bertollo LAC, Moreira-Filho O. Gene mapping of 5S rDNA sites in eight fish species from the Paraíba do Sul river basin, Brazil. Cytogenet Genome Res [serial on the Internet]. 2004; 106(1):107-10. Available from: https://doi. org/10.1159/000078567

Levan A, Fredga K, Sandberg AA. Nomenclature for centromeric position on chromosomes. Hereditas [serial on the Internet]. 1964; 52(2):201-20. Available from: https://doi. org/10.1111/j.1601-5223.1964.tb01953.x

Lui RL, Blanco DR, Margarido VP, Moreira-Filho O. Chromosome characterization and biogeographic relations among three populations of the driftwood catfish Parauchenipterus galeatus (Linnaeus, 1766) (Siluriformes: Auchenipteridae) in Brazil. Biol J Linn Soc Lond [serial on the Internet]. 2010; 99(3):648-56. Available from: https://doi.org/10.1111/j.10958312.2009.01389.x

Lui RL, Blanco DR, Moreira-Filho O, Margarido VP. Propidium iodide for making heterochromatin more evident in the C-banding technique. Biotech Histochem [serial on the Internet]. 2012; 87:433-38. Available from: https://doi.org/10 .3109/10520295.2012.696700

Lundberg JG, Littmann MW. Family Pimelodidae (Longwhiskered catfishes). In: Reis RE, Kullander SO, Ferraris CJ, Jr., organizers. Check list of the freshwater fishes of South and Central America. Porto Alegre: Edipucrs; 2003. p.432-446.

Lundberg JG, Sullivan JP, Hardman M. Phylogenetics of the South American catfish family Pimelodidae (Teleostei: Siluriformes) using nuclear and mitochondrial gene sequences. Proc Acad Nat Sci Phila [serial on the Internet]. 2011; 161(1):153-89. Available from: https://doi.org/10.1635/053.161.0110

Margarido VP, Moreira-Filho O. Karyotypic differentiation through chromosome fusion and number reduction in Imparfinis hollandi (Ostariophysi, Heptapteridae). Genet Mol Biol [serial on the Internet]. 2008; 31(1):235-38. Available from: http:// dx.doi.org/10.1590/S1415-47572008000200012

Mariotto S, Centofante L, Vicari MR, Artoni RF, Moreira-Filho O. Chromosomal diversification in ribosomal DNA sites in Ancistrus Kner, 1854 (Loricariidae, Ancistrini) from three hydrographic basins of Mato Grosso, Brazil. Comp Cytogenet [serial on the Internet]. 2011; 5(4):289-300. Available from: http://doi.org/10.3897/CompCytogen.v5i4.1757

Martinez JF, Lui RL, Blanco DR, Traldi JB, Silva LF, Venere PC, Souza IL, Moreira-Filho O. Comparative cytogenetics of three populations from the Rhamdia quelen species complex (Siluriformes, Heptapteridae) in two Brazilian hydrographic basins. Caryologia [serial on the Internet]. 2011; 64(1):121-28. Available from: https://doi.org/10.1080/00087114.2011.10589772

Martins C, Galetti-Junior PM. Chromosomal localization of 5S rDNA genes in Leporinus fish (Anostomidae, Characiformes). Chromosome Res. 1999; 7(5):363-67.
Martins C, Galetti-Junior PM. Two 5S rDNA arrays in Neotropical fish species: is it a general rule for fishes? Genetica. 2001; 111(1-3):439-46.

Martins C, Wasko AP. Organization and evolution of $5 \mathrm{~S}$ ribosomal DNA in the fish genome. In: Williams CR, editor. Focus on Genome Research. New York: Nova Biomedical Books; 2004. p.335-363.

Martins-Santos IC, Júlio-Júnior HF, Burin I. Karyotypic studies of four species of the Sorubiminae subfamily (Pisces, Siluriformes). Caryologia. 1996; 49(1):73-80.

Matoso DA,Almeida-ValVMF, Silva M, Moraes-Neto A, Almeida MC, Vicari MR, Moreira-Filho O, Artoni RF. Chromosomal polymorphism in Steindachneridion melanodermatum Garavello, 2005 (Siluriformes, Pimelodidae): a reappraisal the existence of sex chromosome system in the species. Rev Fish Biol Fish [serial on the Internet]. 2011; 21:497-508. Available from: https://doi.org/10.1007/s11160-011-9201-2

Mazzuchelli J, Swarça AC, Dias AL. Structural chromosome polymorphism in a Pimelodus maculatus La Cepède, 1803 population (Siluriformes, Pimelodidae) from the Paranapanema River Basin, PR, Brazil. Braz J Bio. 2007; 67:935-37.

Moraes-Neto A, Silva M, Matoso DA, Vicari MR, de Almeida MC, Collares-Pereira MJ, Artoni RF. Karyotype variability in neotropical catfishes of the family Pimelodidae (Teleostei: Siluriformes). Neotrop Ichthyol [serial on the Internet]. 2011; 9(1):97-105. Available from: http://dx.doi. org/10.1590/S1679-62252011005000002

Nirchio M, Mujica A, Oliveira C, Granado A, Mora J, Hett AK, Rossi AR, Milana V, Sola L. Pseudoplatystoma metaense and $P$. orinocoense (Siluriformes: Pimelodidae) from the Orinoco basin, Venezuela: cytogenetic and molecular analyses. Ital J Zool. 2013; 80(4):526-35.

Nirchio M, Rossi AR, Foresti F, Oliveira C. Chromosome evolution in fishes: a new challenging proposal from Neotropical species. Neotrop Ichthyol. 2014; 12(4):761-70.

Pinkel D, Straume T, Gray JW. Cytogenetic analysis using quantitative, high-sensitivity, fluorescence hybridization. Proc Natl Acad Sci USA [serial on the Internet]. 1986; 83(9):2934-38. Available from: https://doi.org/10.1073/ pnas.83.9.2934

Porto-Foresti F, Andreata AA, Oliveira C, Foresti F. The karyotype of Pseudoplatystoma fasciatum from the Rio Paraguay basin (Teleostei, Siluriformes). Chrom Sci. 2000; 4:99-102.

Ramirez-Gil H, Feldberg E, Almeida-Val VMF, Val AL. Karyological, biochemical, and physiological aspects of Callophysus macropterus (Siluriformes, Pimelodidae) from the Solimões and Negro rivers (Central Amazon). Braz J Med Biol Res [serial on the Internet].1998; 31(11):144958. Available from: http://dx.doi.org/10.1590/S0100879X1998001100014

Ribeiro LB, Matoso DA, Almeida MC, Vicari MR, MoraesNeto A, Svidnicki MC, Artoni RF. Karyotypic variability in Iheringichthys labrosus (Teleostei, Pimelodidae) from the Tibagi River basin (Parana State, Brazil). Genet Mol Res. 2008; 7(3):718-24.

Ribeiro FRV, Lucena CAS, Oyakawa OT. A new species of Pimelodus La Cépède, 1803 (Siluriformes: Pimelodidae) from rio Ribeira de Iguape basin, Brazil. Neotrop Ichthyol [serial on the Internet]. 2011; 9(1):127-34. Available from: http://dx.doi.org/10.1590/S1679-62252011000100011 
Rocha MS. Sistemática da família Pimelodidae Swainson, 1838 (Teleostei: Siluriformes). [PHD Thesis on the Internet]. Manaus: Instituto Nacional de Pesquisas da Amazônia (INPA); 2012 [cited March, 29, 2018]. Avalaible from: Biblioteca Digital do Instituto Nacional de Pesquisas da Amazônia. http:// bdtd.inpa.gov.br/handle/tede/1502

Sanchez S, Swarça AC, Fenocchio AS. Cytogenetic studies and evolutive considerations in species of the Calophysus group (Siluriformes, Pimelodinae). Cytologia [serial on the Internet]. 2010; 75(3):223-27. Available from: https://doi.org/10.1508/ cytologia.75.223

Sanchez S, Swarça AC, Fenocchio AS. Cytogenetics analyses among populations of the fish Iheringichtys labrosus (Kröyer, 1874) (Siluriformes, Pimelodidae). Karyotype analysis, C- banding and AgRONs distribution. Brazil J Biol. 2014; 74(1):212-16

Sczepanski TS, Vicari MR, de Almeida MC, Nogaroto V, Artoni RF. Chromosomal organization of repetitive DNA in Sorubim lima (Teleostei; Pimelodidae). Cytogenet Genome Res. 2013; 141:309-16.

Souza L, Giuliano-Caetano L, Dias AL. Karyotypic study of three species of Pimelodus (Pisces, Pimelodidae) from the Paraguai River Basin. Cytologia [serial on the Internet]. 2003; 68(4):34550. Available from: https://doi.org/10.1508/cytologia.68.345

Souza L, Giuliano-Caetano L, Dias AL. Banding chromosome pattern of two species of Pimelodus (Siluriformes, Pimelodidae) from the Paraná river basin of Brazil. Folia Biol (Kraków). 2004; 52:165-69.

Sumner AT. A simple technique for demonstrating centromeric heterochromatin. Exp Cell Res [serial on the internet]. 1972; 75:304-06. Available from: https://doi.org/10.1016/00144827(72)90558-7

Swarça AC, Cestari MM, Giuliano-Caetano L, Dias AL. Cytogenetic characterization of the large South American siluriform fish species Zungaro zungaro (Pisces, Pimelodidae). Chrom Sci. 2001b; 5:51-55.

Swarça AC, Dias AL, Fenocchio AS. Cytogenetic studies in the redtail catfish, Phractocephalus hemioliopterus (Bloch \& Schneider, 1801) (Siluriformes, Pimelodidae) a giant fish from Amazon basin. Comp Cytogen. 2017; 11(1):119-28.

Swarça AC, Fenocchio AS, Cestari MM, Bertollo LAC, Dias AL. Heteromorphic sex chromosome system with an exceptionally large Y chromosome in a catfish Steindachneridion sp. (Pimelodidae). Cytogenet Genome Res. 2006; 112:325-28.

Swarça AC, Fenocchio AS, Cestari MM, Dias AL. Analyses of the structure of NORs in two species of South American Sorubiminae fishes (Siluriformes) by means of several cytogenetic techniques. Folia Biol (Kraków). 2008; 56(12):31-35.

Swarça AC, Fenocchio AS, Cestari MM, Dias AL. First chromosome data on Steindachneridion scripta (Pisces, Siluriformes, Pimelodidae) from Brazilian Rivers: Giemsa, CBG, G- and RE banding. Genet Mol Res. 2005a; 4(4):734-41.

Swarça AC, Fenocchio AS, Cestari MM, Dias AL. Karyotype divergence among populations ofgiant catfish Pseudoplatystoma corruscans (Teleostei: Pimelodidae) indicates higher species diversity. Ichthol Explor Fresh. 2005b; 16(4):325-30.
Swarça AC, Fenocchio AS, Cestari MM, Dias AL. Localization and characterization of the $5 \mathrm{~S}$ rDNA bearing chromosome in two Steindachneridion species by means of different cytogenetic techniques. Cytologia. 2009; 74(3):323-27.

Swarça AC, Fenocchio AS, Dias AL. An update cytogenetic review for species of the Families Pseudopimelodidae, Pimelodidae and Heptapteridae (Pisces, Siluriformes). Suggestion of a cytotaxonomical classification. Caryologia. 2007; 60(4):338-48.

Swarça AC, Giuliano-Caetano L, Dias AL. Cytogenetic characterization through chromosomic banding of Pinirampus pirinampus (Pisces, Pimelodidae) from the Tibagi River basin PR, Brazil. Caryologia. 1999; 52(1-2):31-35.

Swarça AC, Giuliano-Caetano L, Vanzela ALL, Dias AL. Heteromorphism of rRNA genes in Pinirampus pirinampu (Pisces, Pimelodidae) detected by in situ hybridization. Cytologia. 2001c; 66:275-78.

Swarça AC, Giuliano-Caetano L, Dias AL. Analyses of nucleolus organizer regions and heterochromatin of Pimelodus maculatus (Pisces, Pimelodidae). Genetica. 2001a; 110:97-100.

Swarça AC, Sanchez S, Dias AL, Fenocchio AS. Cytogenetics of the Porthole Shovelnose Catfish, Hemisorubim platyrhynchos (Valenciennes, 1840) (Siluriformes, Pimelodidae), a widespread species in South American rivers. Comp Cytogen. 2013; 7(2):1-8.

Treco FR, Malabarba LR, Giuliano-Caetano L, Dias AL. Cytogenetic study of two species of the family Pimelodidae (Siluriformes) collected in lago Guaíba, Rio Grande do Sul, Brazil. Neotrop Ichthyol [serial on the Internet]. 2008; 6(1):87-92. Available from: http://dx.doi.org/10.1590/S167962252008000100010

Treco FR, Dias AL. Karyotypes of two species of the genus Pimelodus (Siluriformes, Pimelodidae). Folia Biol (Krakow) [serial on the Internet]. 2009; 57(1-2):43-48. Available from: https://doi.org/10.3409/fb57_1-2.43-48

Vasconcelos CD, Martins-Santos IC. Chromosome polymorphism in species of the Pimelodidae family (Pisces, Siluriformes). Hereditas [serial on the Internet]. 2000; 132(2):103-09. Available from: https://doi.org/10.1111/j.1601-5223.2000.00103.x

Vissotto PC, Foresti F, Oliveira C. Karyotype description of five species of Pimelodidae (Teleostei, Siluriformes). Chrom Sci. 1999b; 3:1-7.

Vissotto PC, Foresti F, Oliveira C. Supernumerary chromosomes in two species of the family Pimelodidae (Teleostei, Siluriformes). Chrom Sci. 1999a; 3:9-13. 